\title{
Potential of oligosaccharides from inulin in human nutrition and health
}

\author{
Shavnam Thakur, Adnan A. Khan* and Wamik Azmi* \\ Department of Biotechnology, Himachal Pradesh University, Shimla-171005, Himachal Pradesh, India \\ *Division of Nephrology and Hypertension, Department of Medicine, University of California, San Diego, Suite Plaza 1, 4510 Execute Drive, \\ San Diego-92121, USA
}

\begin{tabular}{l} 
Article Info \\
\hline Article history \\
Received 9 April 2020 \\
Revised 26 May 2020 \\
Accepted 29 May 2020 \\
Published online 30 June 2020 \\
\hline
\end{tabular}

Keywords

Fructo-oligosaccharides

Inulo-oligosaccharides

Inulin

Inulinase

Prebiotics

\begin{abstract}
Inulins are linear fructan polymers which contain fructose units joined by $\beta-2,1$ glycosidic bonds, typically terminating in a glucose residue linked by an $\alpha-1,2$ bond as in sucrose. The major source of inulin is plants like Jerusalem artichoke and chicory root. Fructo-oligosaccharides consist of a fructose units polymerized to different extent and can be formed in vitro from substrate such as inulin. These oligosaccharides can be produced from the enzymatic hydrolysis of inulin by inulinase under controlled reaction conditions. In recent years, the oligosaccharides production has revolve around it's cost effective production from inexpensive and abundantly available raw materials. Inulin is a very promising source for oligosaccharide production. An exoinulinase and invertase activities free endoinulinase is required to acts on inulin because these two enzymes contaminate the final products with release of free sugars, which subsequently require more stringent purification protocols. Oligosaccharides obtained from inulin have similar chemical structures to fructo-oligosaccharides which were obtained by reaction of fructosyltransferase on sucrose. These oligosaccharides are regarded as a soluble dietary fiber, non-cariogenic, of low caloric value and showed strong bifidus-factors. They have proven health benefits which include role in absorption of calcium and minerals, replacement of sugar and fat in food products, reduction in cholesterol and ability to control cancer.
\end{abstract}

\section{Introduction}

The name inulin was given after this compound was first isolated from Inula helenium (Azis et al., 1999). Inulin is the second most abundant storage carbohydrate after starch in plants and many plants have been shown to make inulin as a storage polysaccharide. Inulin is a linear fructan polymer which mainly comprises of $\beta-2$, 1-D-fructofuranose linked with a glucose unit at the terminal end. It is a part of dietary fiber and does not get digested by human. Large quantity of inulin is found in plants like Jerusalem artichoke and roots of chicory, asparagus, burdock, yacon, camas and dandelion. Inulin is also present in common plants, vegetables and fruits like garlic, banana, onion, leek, wheat, rye, barley, jicama, salisfy and coneflower (Mensink et al., 2015). This fructan is a potential substrate for generation of high fructose syrup and prebiotic inulooligosaccharides (IOSs). These value added products can be produced using microbial inulolytic enzymes. Inulin is acted upon by two types of inulinases, i.e., endoinulinase $(2,1-\beta-\mathrm{D}$ fructanfructanohydrolase, EC 3.2.1.7) and exoinulinase ( $\beta$-Dfructanfructohydrolase, EC 3.2.1.80). Exoinulinases hydrolyze the terminal linkages of inulin to yield fructose as the main product (Germec and Turhan, 2020) while endoinulinases produce IOSs as the main product (Figure 1). Inulo-oligosaccharides (IOSs) are a novel food additive and health products which represent a promising

Corresponding author: Dr. Wamik Azmi

Professor, Department of Biotechnology, Himachal Pradesh University, Shimla-171005, Himachal Pradesh, India

E-mail: wamikazmi@rediffmail.com

Tel.: +91-177-2831948

Copyright $(\mathcal{C} 2020$ Ukaaz Publications. All rights reserved.

Email: ukaaz@yahoo.com; Website: www.ukaazpublications.com alternative to antibiotics. IOSs as prebiotics can be obtained by endoinulinase mediated hydrolysis of inulin.

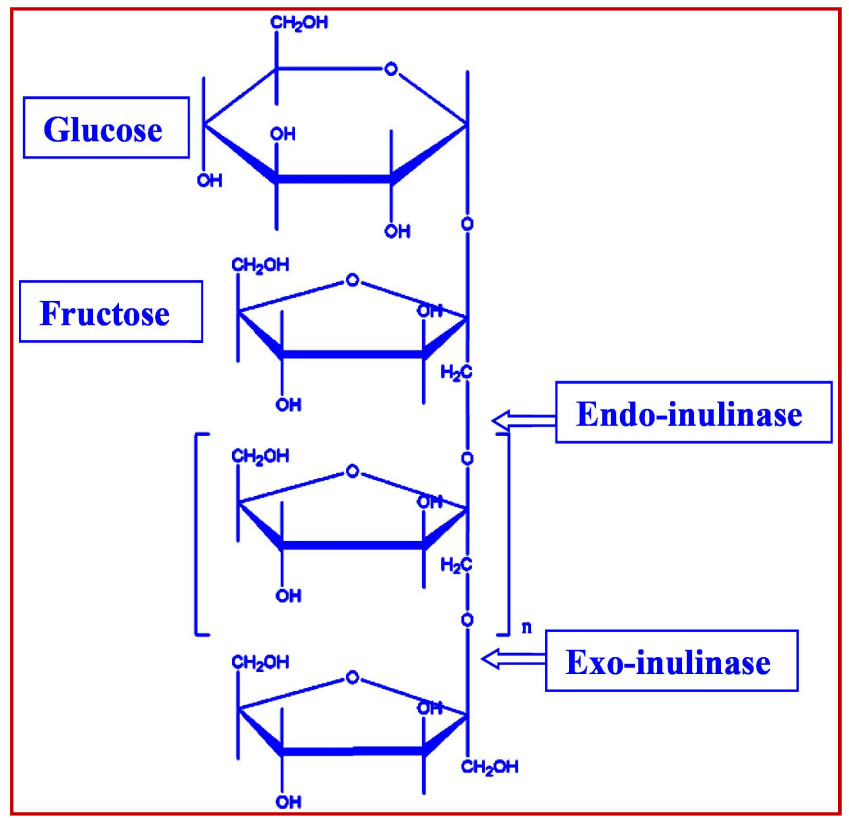

Figure 1: Structure of inulin, a linear fructosyl polymer linked by $\beta-(2,1)$ bonds $(n=3-65)$ attached to a terminal glucosyl residue by an $\alpha$ $(1,2)$ bond. The exo-inulinase catalyzes removal of the terminal fructose residues from the non-reducing end of the inulin molecule in one step, producing fructose and glucose. The endoinulinase hydrolyzes inulin to produce IOSs from inulin. 
The fructo-oligosaccharides (FOSs) derived from inulin are referred to as inulo-oligosaccharides but it's chemical structure is similar to fructooligosaccharides. FOSs consist of a fructose units polymerized to different extent. Oligomers with two, three and four fructose units are called as 1-kestose, 1-nystose and 1fructofuranosyl-nystose, respectively. The sugars are linked by $\beta$ 2, 1 position of sucrose. FOSs have been designated as prebiotics due to their bifidogenic nature. They also possessed many healthpromoting properties when consumed in suggested amounts recommended by health practitioners (Nguyen et al., 2011). Majority of health benefits and nutritional applications of these oligosaccharides in human are well recognized. These include the resistance to various infections by activation of the immune system, enhanced calcium absorption in the gastrointestinal tract and provide support in the synthesis of vitamin B-complex (Yun, 1996; Tanriseven and Aslan, 2005).

Probiotics are potentially beneficial bacteria (mainly Bifidobacterium and Lactobacilli) that commensal to the colon of a person. Prebiotics have the capability to stimulate the multiplication of probiotics by the associated suppression of potentially pathogenic bacteria (Van Laere et al., 2000). However, synbiotics nutraceuticals is the combination of prebiotics and probiotics in food and other fermented dairy products such as yogurt, that have the ability to influence and improve the gastrointestinal health of humans (Huebner et al., 2007). The main feature of prebiotic food ingredient is that it should not be hydrolysed or absorbed in the upper part of the gastrointestinal tract of a person. Further, it should act as a selective substrate to only few probiotics and have the ability to alter the colonic microflora to potentially more healthy micro-organisms.

The importance of FOSs as food ingredients is due to the various biological properties they possessed (Villegas and Costell, 2007). These oligosaccharides have very low sweetness intensity as they are about one third as sweet as sucrose. This property is useful in the various foods especially for diabetic persons where the use of sucrose is restricted by its high sweetness. FOSs have low calorie levels as it does not get digested by human and are not used as an energy source in the body and due to this thay are safe for consumption by diabetics (Sangeetha et al., 2005). The FOSs also encourage the growth of the Bifidobacterium and Lactobacilli as prebiotics and discourage the growth of potentially harmful microorganisms that have a tendency to cause diseases. The formation of lactic, acetic and other short-chain organic acids is the possible reasons of the suppression of the growth of harmful bacteria in the gut (Biedrzyka and Bielecka, 2004). These molecules may act as antagonist to the potentially pathogenic intestinal competitors. FOSs are noncariogenic. They are not used by Streptococcus mutans to form acids and insoluble $\beta$-glucan which are the major factor in the formation of dental caries.

\section{Biotechnological production of inulo-oligosaccharide}

Prebiotics IOSs can be produced enzymatically from sucrose elongation or via enzymatic hydrolysis of inulin by endoinulinases. Inulin is a naturally occurring storage polysaccharide present in numerous plants, such as Jerusalem artichoke and IOSs can be obtained by endoinulinase mediated hydrolysis of it. Inulin and oligofructose have wide applications in various types of foods like confectionery, fruit preparations, milk desserts, yogurt and fresh cheese, baked goods, chocolate, ice cream and sauces (Cabezas et al., 2002; Kaur and Gupta, 2002). IOSs are novel food additive and health product and also represent a promising alternative to antibiotics. IOSs as prebiotics can be obtained from inulin by endoinulinase catalyzed hydrolysis. Nonetheless, enzymatic catalysis is not a very feasible option industrially because of the required catalytic conditions and cost. In recent years, researcher's attention has been shifted to use of microorganisms for conversion of naturally and abundantly available raw materials for the production of oligosaccharides. In this regard, inulin is a promising source for oligosaccharide production when subjected to the action of endoinulinase enzyme of microbial origin. The absences of exoinulinase or invertase activities are prerequisite as presence of these enzymes in micro-organism form undesirable side products. It has been reported that many filamentous fungi and bacterial strains can produce endoinulinase (Chi et al., 2009). The chemical structures IOSs obtained from inulin is similar to FOSs from sucrose and they have been used as a soluble dietary fiber. The endoinulinase can be applied to hydrolyze inulin to produce IOSs but Hughes et al., (2017) have observed that a microorganism requires an extracellular inulinase to hydrolyze the glycosidic bonds to release fermentable monosaccharides in order to directly utilize inulin as its carbon and energy source. Some of the microorganisms and their optimum conditions for IOSs production have been summarized in Table 1.

Shukla, (2019) suggested that free inulinase has restricted applications at the industrial level because of its limited functional and storage stability and difficulty in recovery from the reaction mixture. Free enzyme also undergoes irreversible inactivation due to aggregation. Hence, the use of immobilized enzyme has generally been considered as better option for biotransformation reactions. Continuous production of IOSs from pure inulin was achieved by the use of immobilized endoinulinase obtained from Pseudomonas sp. The immobilized endoinulinase was found to be quite stable and can work for 15 days at $55^{\circ} \mathrm{C}$. This continuous system record oligosaccharide yield of $83 \%$ without any loss of initial enzyme activity (Yun et al., 1997a). IOSs were also produced from inulin by using a purified commercial endoinulinase with $96 \%$ yield of oligosaccharide. The degree of polymerization (DP) of the major oligosaccharides obtained was 3 and 4 (Yun et al., 1997b). The endoinulinase gene (inul) of Pseudomonas sp. was cloned and expressed in Escherichia coli $\mathrm{HBlOl}$ and was used to produce IOSs from inulin (78\% yield). This recombinant E. coli expressing endoinulinase enzyme was immobilized on a polystyrene carrier material. The immobilization of endoinulinase results in enhanced thermal stability of the enzyme. A bioreactor packed with the immobilized cells was used for continuous production of IOSs from inulin. The continuous production of IOSs was successfully achieved with the productivity of $150 \mathrm{~g} / \mathrm{l} / \mathrm{h}$ for $17 \mathrm{~d}$ at $50^{\circ} \mathrm{C}$ (Yun et al., 1999).

Batch mode of production of IOSs from inulin was attempted by an endoinulinase obtained from Xanthomonas with a yield of about $86 \%$. The major IOSs components in the reaction were of DP 5 and 6 (Park et al., 1999). Pure inulin and chicory extract were used to hydrolyze for IOSs production by endoinulinase from Xanthomonas oryzae No. 5. DP5 and higher oligosaccharides were found to be major reaction products in case of both chicory extract and pure inulin as the substrates (Cho et al., 2001). Inulotriose with a yield of $70 \%$ was obtained as the main product by the action of an endoinullnase P-II produced by Penicillium sp. TN-88 (Nakamura et al., 1997). Further, this endonuclease does not show any activity toward other sugars like sucrose, raffinose or levan. Mutanda et al., (2008) used purified endoinulinase $(60 \mathrm{U} / \mathrm{ml})$ from Aspergillus niger to hydrolyse inulin $(150 \mathrm{mg} / \mathrm{ml})$ at $60^{\circ} \mathrm{C}$ for $48 \mathrm{~h}$. The major oligosaccharides obtained from inulin were inulotrioses, inulotetraoses and inulopentaoses with yield of 70.3, 38.8 and $3.5 \mathrm{mM}$, respectively. 
Table 1: Some microbial endoinulinases used for IOSs formation from inulin

\begin{tabular}{|c|c|c|c|c|c|c|}
\hline Source of endoinulinase & \begin{tabular}{|l|} 
Reaction \\
$\mathrm{pH}$
\end{tabular} & \begin{tabular}{|l|} 
Hydrolysis \\
temperature
\end{tabular} & \begin{tabular}{|l} 
Incubation \\
time
\end{tabular} & Substrate used & \begin{tabular}{|l|}
$\begin{array}{l}\text { DP of formed } \\
\text { oligosaccharides }\end{array}$ \\
\end{tabular} & Reference \\
\hline Recombinant Pichia pastoris & 6 & 60 & $8 \mathrm{~h}$ & $400 \mathrm{~g} / \mathrm{L}$ Inulin & $2-5$ & He et al., 2014 \\
\hline pseudomonas sp. & 5.5 & 55 & $5 \mathrm{~h}$ & $50 \mathrm{~g} / \mathrm{L}$ Inulin & $2-7$ & Kim et al., 1997 \\
\hline Pseudomonas mucidolens & 7.0 & 50 & $30 \mathrm{~h}$ & - & $2-5$ & Kim et al., 2006 \\
\hline Recombinant Bacillus subtilis & 7.4 & 32 & $48 \mathrm{~h}$ & $20 \mathrm{~g} / \mathrm{L}$ Inulin & $3-5$ & Jiang et al., 2019 \\
\hline Recombinant $S$. cerevisiae & 5 & $40^{\circ} \mathrm{C}$ & 24 & $200 \mathrm{~g} / \mathrm{L}$ chicory & $3-6$ & Wang et al., 2016a \\
\hline Recombinant E. coli & 4.6 & 55 & 24 & $15 \mathrm{~g} / \mathrm{L}$ Inulin & $3-7$ & Wang et al., 2016b \\
\hline Recombinant E. coli & 5 & 55 & 24 & $50 \mathrm{~g} / \mathrm{L}$ Inulin & $3-4$ & Chen et al., 2012 \\
\hline Aspergillus ficuum & 5 & 45 & 72 & $50 \mathrm{~g} / \mathrm{L}$ Inulin & $2-8$ & Jin et al., 2005 \\
\hline Chrysosporium pannorum & $6-7$ & 50 & 24 & $30 \mathrm{~g} / \mathrm{L}$ Inulin & $3-5$ & Xio et al., 1989 \\
\hline Xanthomonas sp. & 7 & 37 & 22 & $5 \mathrm{~g} / \mathrm{L}$ Chicory powder & - & Park and Yun, 2001 \\
\hline Pseudomonas Sp. & 6.5 & 42 & 22 & $5 \mathrm{~g} / \mathrm{L}$ Chicory powder & - & Park and Yun, 2001 \\
\hline $\begin{array}{l}\text { Xanthomonas campestris } \\
\text { pv. phaseoli KM } 24\end{array}$ & 6.0 & 50 & 2 & $5 \mathrm{~g} / \mathrm{L}$ Inulin & $3-5$ & Naidoo et al., 2015 \\
\hline Bacillus safensis AS-08 & 5.5 & 50 & $15 \mathrm{~min}$ & $20 \mathrm{~g} / \mathrm{L}$ Inulin & - & Singh et al., 2013 \\
\hline Aspergillus niger & 6.0 & 60 & $8 \mathrm{~h}$ & $400 \mathrm{~g} / \mathrm{L}$ Inulin & $3-6$ & Xu et al., 2016 \\
\hline $\begin{array}{l}\text { Commercial enzyme } \\
\text { (Novozyme 230) }\end{array}$ & 5.0 & 55 & 24 & $50 \mathrm{gm} / \mathrm{L}$ Inulin & $2-6$ & Yun et al., 1997b \\
\hline
\end{tabular}

A partially purified and purified endoinulinase from $A$. ficuum were used to produce IOSs from inulin by Jin et al., (2005). The $74 \%$ of inulin (initial $50 \mathrm{~g} / \mathrm{l}$ ) was hydrolyzed by the partially purified endoinulinase $\left(10 \mathrm{U} / \mathrm{g}\right.$ substrate) under the optimal conditions at $45^{\circ} \mathrm{C}$ and IOSs yield over $50 \%$ was observed after $72 \mathrm{~h}$. However, $89 \%$ of inulin in the Jerusalem artichoke juice as substrate was hydrolyzed with IOSs production of $80 \%$ after $72 \mathrm{~h}$. The difructose anhydride III was produced as main product by inulin fructotransferase enzyme of soil bacterium Arthrobacter aurescens SK 8.001. Nystose was found to be the smallest substrate for this enzyme and this inulin fructotransferase provides a promising way to utilize inulin for the production of difructose anhydride III (Zhao et al., 2011).

A simple, efficient and one-step bioprocess for IOSs production from inulin through extracellular heterologous endoinulinase by Bacillus subtilis was developed by Jiang et al., (2019). The gene inuQ of Pseudomonas mucidolens encoding endoinulinase was cloned into Bacillus subtilis WB800-R, with the simultaneous deletion of gene sacC encoding levanase. The maximal IOSs yield after hydrolysis of the crude extract of inulin was $68 \mathrm{~g} / 1$ with conversion rate of $75 \%$. The DP of major IOSs obtained was between 3 and 5. The Saccharomyces cerevisiae has many applications in food industry and comes under Generally Recognized as Safe category. The endoinulinase gene (inu1) from Pseudomonas mucidolens was expressed in the cells of $S$. cerevisiae and was used to hydrolyze inulin for production of IOSs with a yield of $71 \%$ under optimized condition after $30 \mathrm{~h}$ of reaction (Kim et al., 2006). This enzyme was found to be stable towards denaturation and DP of formed IOSs a result of the reaction with inulin mainly consist of 4 (inulopentaoses). An efficient conversion of inulin to IOSs through endoinulinase from Aspergillus niger by encoding endoinulinase from A. niger DSM 2466 into Pichia pastoris KM71 was reported by $\mathrm{Xu}$ et al. (2016). Maximum activity $(858 \mathrm{U} / \mathrm{ml})$ of the recombinant endoinulinase was obtained at $120 \mathrm{~h}$ of fermentation. The yield of IOSs was found to be $91.3 \%$ and IOSs with different DP (3-6) were distributed in the final reaction mixture.

\section{Application of oligosaccharides produced from inulin}

The oligosaccgarides obtained from inulin (i.e., IOSs) have a number of desirable features such as low calories, no cariogenicity, safe sweetener for diabetics and promote growth of gut microflora (Figure 2).

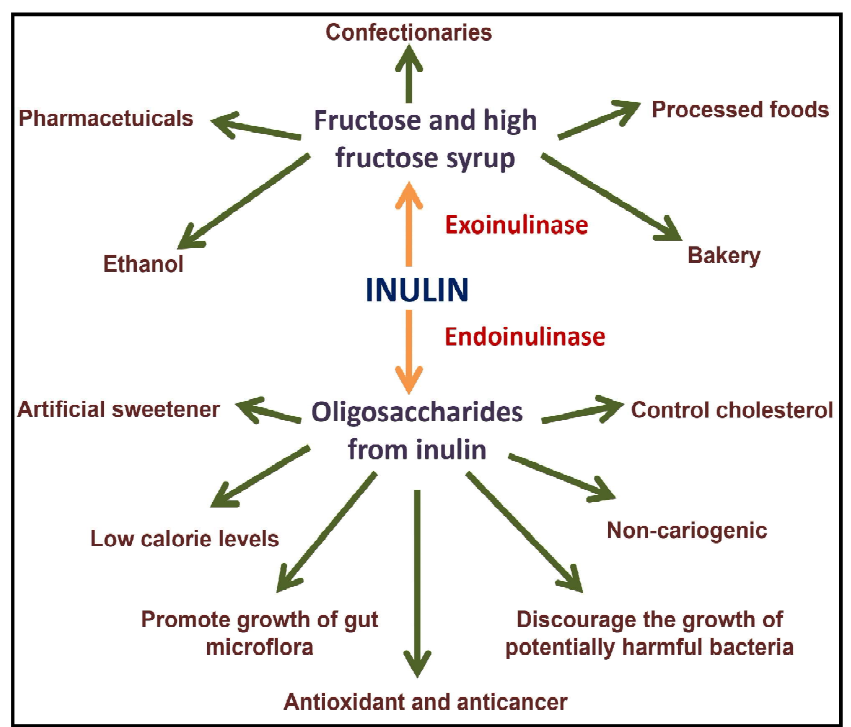

Figure 2: Hydrolysis of inulin by inulinases and major applications of products obtained from inulin.

\subsection{Promotion of growth of the gut micro-oranisms}

The diet and its composition have major impact on gut and its microflora. Any kind of change in the diet affects the metabolism of the inhabitants. The dietary fibres like oligosaccharides exert a combined effect on both the pH environment of the gut and the metabolism of bacterial community (Flint et al., 2007). A study on 
Bifidobacterium conducted by (Palframan et al., (2003) showed that FOSs are preferred carbohydrates as it allow maximum growth and metabolic activities of this beneficial flora in human intestine. The prebiotics such as inulin, FOSs, sorbitol, and arabinan were found to stimulate the growth of Bifidobacterium pseudocatenulatum G4. The fractional factorial and central composite design was found to be very effective tool for optimization of medium for growth of Bifidus. Even isomalto-oligosaccharides were found to stimulate the growth of Lactobacilli as major intestinal microflora of rats.

\subsection{Potential artificial sweetener for diabetics}

Diabetes is one of the major lifestyle associated disorders which and involves malfunctioning of the endocrine system. Diabetes can lead to cardiovascular diseases, renal failure, blindness and even premature death. Apart from many health benefits, FOSs also has artificial sweetness and low caloric as value they are rarely hydrolysed by digestive enzymes. Artificial sweeteners are constantly in demand as person suffering from diabetes and health conscious consumers are major user. Initially this demand was satisfied by aspartame or natural sweeteners palatinose. The popularity of these molecules among common users is major reason for poor exploitation of as artificial sweetener. (Mussatto et al., 2009). Although, all oligosaccharides are exhibiting prebiotic properties but FOSs has gained much attention as artificial sweeteners because they provide sweet taste to the consumer and do not increase the blood glucose level because their unique biological properties that they are remain unutilized in digestive tract. Therefore, they find important place in the food of diabetics and used as artificial sweeteners with functional properties apart from sweetness similar to that of natural sweeteners. Mabel et al., (2008) were able to synthesize mono-to pentasaccharides by Aspergillus oryzae with the possibility of its application as a food ingredient as no toxic microbial metabolites are formed in the process. The diabetic rats were fed on FOSs in order to see its use as an alternative nonnutrient sweetener without any deleterious effects. FOSs did not increase the sugar level in diabetic animals and were also found to decrease the loss of blood protein (Mabel et al., 2008).

\subsection{Other health benefits}

The other important physiological roles of FOSs in human beings include the control of osteoporosis and reduction in the levels of serum cholesterol, phospholipids, and triglycerides. Slevin et al., (2014) reported that the supplementation of these oligosaccharides along with calcium to post menopausal women shown to improve bone mineral density which help in control of osteoporosis. Pierre et al., (1997) have found that supplementation of FOSs may help in protection of colorectal cancer. The protective action of FOSs in the colon might be due to the activity of a short chain fatty acid (butyrate) which has been produced by FOSs in the colon. This butyrate also play role in prevention of tumor growth, cell differentiation and up-regulation of apoptosis. The feeding FOS reported to reduce the development of intestine tumor (Pierre et al., 1997). The anti-cancer effect of FOSs is also due to the immunomodulation in Peyer's patches (Roller et al., 2004). The supplementation of Lactobacillus acidophilus ATCC 4962 along with the prebiotics was evidently found the remove cholesterol (Liong and Shah, 2005). The first-order, second-order polynomial regression and quadratic models were applied to determine the best combination out of six prebiotics including FOSs in effective removal of cholesterol. The inulo, galacto and fructooligosaccharides were found to be very suitable for growth of Bifidobacterium and Lactobacilli (Macfarlane et al., 2008). Their health benefits include anti-cancer properties, calcium and other mineral absorption, lipid metabolism, anti-inflammatory and immune-modulatory effects.

The antioxidant properties of soy protein isolates and FOSs under different testing conditions were studied and glycation and crosslinking of protein was estimated (Mesa et al., 2008). The LDL oxidation and oxygen radical absorbance capacity assays was conducted. It was reported that peptides derived from soy protein scavenged peroxyl radicals and did not protect LDL against copper oxidation. The neoantioxidants formed by thermal degradation of FOSs prevent the LDL oxidation and scavenged peroxylalkyl radicals. Treatment of various infectious diseases or prevention of infection with antibiotics especially penicillin, cephalosporin, and clindamycin are found to be associated with acute diarrhea due to dislodge of normal protective intestinal microflora (Fekety and Shah, 1993). It was observed that the patients taking FOSs were less likely to develop diarrhea during antibiotic treatment. While determining the efficacy of The FOSs-Lactobacillus sporogenes preparation was found to be very effective in prevention of diarrhea due to antibiotics treatment in children (La Rosa et al., 2003). This fact leads to addition of FOSs in many of commercial products to enhance and promote the therapeutic benefits of the probiotic organisms. The application of FOSs also changes the gut microflora of infants and alters the large bowel function.

\section{Conclusion}

Oligosaccharides produced from various inexpensive and abundantly available sources have been considered as a boon due to health benefits they encompass. These oligosaccharides have considered in the health market as nutraceuticals due to the variety of health benefits cthey possessed. The microbial production of enzymes which catalyze the oligosaccharides formation are now targeted by the researchers for their optimum production and novel microorganisms producing potential endoinulinase enzymes are being explored for their capabilities in IOSs production. The scale-up of process from laboratory to production scale is always problematic and challenging. More scale-up studies should be conducted for the development of economically viable bioprocess for production of IOSs at industrial level. The bioprocess improvement should be inculcated using cheaper agro-industrial wastes as substrates for oligosaccharide production. To develop a commercially feasible bioprocess for cost effective production of IOSs, a genetically stable exoinulinase and invertase free endoinulinase hyperproducer is a prerequisite. Moreover, the ability of microorganism to utilize agroindustrial waste and inexpensive protocol for purification of produced oligosaccharides will further strengthen the bioprocess.

\section{Acknowledgements}

Authors acknowledge the support from Department of Biotechnology, Himachal Pradesh University, Shimla, India.

\section{Conflict of interest}

The authors declare that there are no conflicts of interest in the course of conducting the research. All the authors had final decision regarding the manuscript and decision to submit the findings for publication. 


\section{References}

Azis, B.H.; Chin, B.; Deacon, M.P.; Harding, S.E. and Pavlov, G.M. (1999). Size and shape of inulin dimethyl sulphoxide solution. Carbohydrate Polymer, 38:231-234.

Biedrzyka, E. and Bielecka, M. (2004). Prebiotic effectiveness of fructans of different degrees of polymerization. Trends in Food Science and Technology, 15:170-175.

Cabezas, M.J.C.; Bravo, R.S. and Shene, C. (2002). Inulin and sugar contents in Helianthus tuberosus and Cichorium intybus tubers: Effect of postharvest storage temperature. Journal of Food Science, 67:2860-3865.

Chen, X.M.; Xu, X.M.; Jin, Z.Y. and Chen, H.Q. (2012). Expression of an endoinulinase from Aspergillus ficuum JNSP5-06 in Escherichia coli and its characterization. Carbohydrate Polymers, 88:748-753.

Chi, Z.M.; Chi, Z.; Zhang, T.; Liu, G.L. and Yue, L. (2009). Inulinase expressing micro-organisms and applications of inulinases. Applied Microbiology and Biotechnology, 82:211-220.

Cho, Y.J.; Sinha, J.; Park, J.P. and Yun, J.W. (2001). Production of inulooligosaccharides from chicory extract by endoinulinase from Xanthomonas oryzae No. 5. Enzyme and Microbial Technology, 28:439-445.

Fekety, R. and Shah, A.B. (1993). Diagnosisand treatment of Clostridium dijicile colitis. Journal of American Medical Association, 289:71-75.

Flint, H.J.; Duncan, S.H.; Scott, K.P. and Louis, P. (2007). Interactions and competition within the microbial community of the human colon: Links between diet and health. Environmental Microbiology, 9:1101-1111.

Germec, M. and Turhan, I. (2020). Enhanced production of Aspergillus niger inulinase from sugar beet molasses and its kinetic modeling. Biotechnology Letters, https://doi.org/10.1007/s10529-02002913-1(0123456789().,-volV() 0123458697().,)

He, M.; Wu, D.; Wu, J. and Chen, J. (2014). Enhanced expression of endoinulinase from Aspergillus niger by codon optimization in Pichia pastoris and its application in inulooligosaccharide production. Journal of Industrial Microbiology and Biotechnolohy, 41:105-114.

Huebner, J.; Wehling, R.L. and Hutkins, R.W. (2007). Functional activity of commercial prebiotics. International Dairy Journal, 17:770-775.

Hughes, S.R.; Qureshi, N.; Lopez Nunez, J.C.; Jones, M.A.; Jarodsky, J.M.; GalindoLeva, L.A. and Lindquist, M.R. (2017). Utilization of inulincontaining waste in industrial fermentations to produce biofuels and bio-based chemicals. World Journal of Microbiology and Biotechnology, 33:78-92.

Jiang, R.; Qiu, Y.; Huang, W.; Zhang, L.; Xue, F,; Hao Ni, Ho.; Mei, D.; Gao, J. and Xu, H. (2019). One-Step bioprocess of inulin to product inulooligosaccharides using Bacillus subtilis secreting an extracellular endoinulinase. Applied Biochemistry and Biotechnology, 187:116-128

Jin, Z.; Wang, J.; Jiang, B. and Xu, X. (2005). Production of inulooligosaccharides by endoinulinases from Aspergillus ficuum. Food Research International, 38:301-308.

Kaur, N. and Gupta, A.K. (2002). Applications of inulin and oligofructose in health and nutrition. Journal of Biosciences, 27:703-714.

Kim, D.H.; Choi, Y.J.; Song, S.K. and Yun, J.W. (1997). Production of inulooligosaccharides using endo-inulinase from a pseudomonas sp. Biotechnology Letters, 19:369-371.
Kim, H.C.; Kim, H.J.; Choi, W.B. and Nam, S.W. (2006). Inulooligosaccharide production from inulin by Saccharomyces cerevisiae strain displaying cell-surface endoinulinase. Journal of Microbiology and Biotechnology, 16:360-367.

La Rosa, M.; Bottaro, G.; Gulino, N.; Gambuzza, F.; Di Forti, F., Ini, G. and Tornambe, E. (2003). Prevention of antibiotic-associated diarrhoea with Lactobacillus sporogenes and fructo-oligosaccharides in children. A multicenter double-blind vs. placebo study. Minerva Pediatrics, 55:447-452.

Liong, M.T. and Shah, N.P. (2001). Optimization of cholesterol removal, growth and fermentation patterns of Lactobacillus acidophilus ATCC4962 in the presence of mannitol, fructo-oligosaccharide and inulin: A response surface methodology approach. Journal of Applied Microbiology, 98:1115-1126.

Mabel, M.J.; Sangeetha, P.T.; Platel, K.; Srinivasan, K. and Prapulla, S.G. (2008). Physicochemical characterization of fructooligosaccharides and evaluation of their suitability as a potential sweetener for diabetics. Carbohydrate Research, 343:56-66.

Macfarlane, G.T.; Steed, H. and Macfarlane, S. (2008). Bacterial metabolism and health-related effects of galacto-oligosaccharides and other prebiotics. Journal of Applied Microbiology, 104:305-344.

Mensink, M.A.; Frijlink, H.W.; van der Voort Maarschalk, K. and Hinrichs, W.L.J. (2015). Inulin, a flexible oligosaccharide I: review of its physicochemical characteristics. Carbohydrate Polymer, 130:405-419.

Mesa, M.D.; Silvan, J.M.; Olza, J.; Gil, A. and del Castillo, M.D. (2008). Antioxidant properties of soy protein-fructo-oligosaccharide glycation systems and its hydrolyzates. Food Research International, 41:606-615.

Mussatto, S.I.; Aguilar, C.N.; Rodrigues, L.R. and Teixeira, J.A. (2009). Fructooligosaccharides and $\beta$-fructofuranosidase production by Aspergillus japonicus immobilized on lignocellulosic materials. Journal of Molecular Catalysis B Enzyme, 59:76-81.

Mutanda, T.; Wilhelmi, B.S. and Whiteley, C.G. (2008). Response surface methodology: Synthesis of inulooligosaccharides with an endoinulinase from Aspergillus niger. Enzyme Microbial Technology, 43:362-368.

Naidoo, K.; Kumar, A.; Vikas Sharma, S.; Permaul, K. And Singh, S. (2015). Purification and Characterization of an Endoinulinase from Xanthomonas campestris pv. phaseoli KM 24 Mutant. Food Technology and Biotechnology, 53:146-153.

Nakamura, T.; Shitara, A.; Matsuda, S.; Matsuo, T.; Suiko, M. and Ohta, K. (1997). Production, purification and properties of an endoinulinase of Penicillium sp. TN-88 that liberates inulotriose. Journal of Fermentation and Bioengineering, 84:313-318.

Nguyen, Q.D.; Rezessy-Szabo, J.M.; Czukor, B. and Hoschke, A. (2011). Continuous production of oligofructose syrup from Jerusalem artichoke juice by immobilized endo-inulinase. Process Biochemistry, 46:298-303.

Palframan, R.; Gibson, G.R. and Rastall, R.A. (2003). Effect of $\mathrm{pH}$ and dose on the growth of gut bacteria on prebiotic carbohydrates in vitro. Anaerobe, 8:287-292.

Park, J.P. and Yun, J.W. (2001). Utilization of chicory roots for microbial endoinulinase production. Letters in Applied Microbiology, 33:183187.

Park, J.P.; Bae, J.T.; You, D.J.; Kim, B.W. and Yun, J.W. (1999). Production of inulo-oligosaccharides from inulin by a novel endoinulinase from Xanthomonas sp. Biotechnology Letters, 21:1043-1046. 
Pierre, F.; Perrin, P.; Champ, M.; Bornet, F.; Meflah, K. and Menanteau, J. (1997). Short-chain fructo-oligosaccharides reduce the occurrence of colon tumors and develop gut-associated lymphoid tissue in Min mice. Cancer Research, 57:225-228.

Roller, M.; Rechkemmer, G. and Watzl, B. (2004). Prebiotic inulin enriched with oligofructose in combination with the probiotics Lactobacillus rhamnosus and Bifidobacterium lactis modulates intestinal immune functions in rats. Journal of Nutrition, 134:153-156.

Sangeetha, P.T.; Ramesh, M.N. and Prapulla, S.G. (2005). Recent trends in the production, analysis and application of Fructo-oligosaccharides. Trends in Food Science and Technology, 16:442-457.

Shukla, P. (2019). Synthetic biology perspectives of microbial enzymes and their innovative applications. Indian Journal of Microbiology, 59:401-409.

Singh, R.S.; Singh, R.P. and Yadav, M. (2013). Molecular and biochemical characterization of a new endoinulinase producing bacterial strain of Bacillus safensis AS-08. Biologia, 68:1028-1033.

Slevin, M.M.; Allsopp, P.J.; Magee, P.J.; Bonham, M.P.; Naughton, V.R.; Strain, J.J.; Duffy, M.E.; Wallace, J.M. and Mac Sorley, E.M. (2014). Supplementation with calcium and short-chain fructo-oligosaccharides affects markers of bone turnover but not bone mineral density in postmenopausal women. Journal of Nutrition, 144:297-304.

Tanriseven, A. and Aslan, Y. (2005). Immobilization of Pectinex Ultra SP-L to produce fructo-oligosaccharides. Enzyme and Microbial Technology, 36:550-554.

Van Laere, K.M.J.; Abee. T.; Schools, H.A.; Beldman, G. and Voragen, A.G.J. (2000). Characterization of a novel $\beta$-galactosidase from Bifidobacterium adolescentis DSM 20083 active towards transgalacto-oligosaccharides. Applied and Environmental Microbiology, 66:1379-1384.

Villegas, B. and Costell, E. (2007). Flow behaviour of inulin-milk beverages. Influence of inulin average chain length and of milk fat content. International Dairy Journal, 17:776-781.
Wang, D.; Li, F.L. and Wang, S.A. (2016a). A one-step bioprocess for production of high-content fructooligosaccharides from inulin by yeast. Carbohydrate Polymers, 151:1220-1226.

Wang, P.P.; Ma, J.F.; Zhang, Y.; Zhang, M.; Wu, M.K.; Dai, Z.X. and Jiang, M. (2016b). Efficient secretory overexpression of endoinulinase in Escherichia coli and the production of inulo-oligosaccharides. Applied Biochemistry and Biotechnology, 179:880-894.

Xiao, R.; Tanida, M. and Takao, S. (1989). Purification and some properties of endoinulinase from Chrysosporium pannorum. Journal of Fermentation and Bioengineering, 67:244-248.

Xu, Y.; Zheng, Z.; Xu,Q.; Yong, Q. and Quyang, J. (2016). Efficient Conversion of inulin to inulo-oligosaccharides through endoinulinase from Aspergillus niger. Journal of Agricultural and Food Chemistry, 64:2612-2618.

Yun, J.W. (1996). Fructooligosaccharides occurrence, preparation, and application. Enzyme and Microbial Technology, 19:107-117.

Yun, J.W.; Choi, Y.J.; Song, C.H. and Song, S.K. (1999). Microbial production of inulo-oligosaccharides by an endoinulinase from Pseudomonas sp. expressed in Escherichia coli. Journal of Bioscience and Bioengineering, 81:291-295.

Yun, J.W.; Kim, D.H.; Kim, B.W. and Song, S.K. (1997a). Production of inulooligosaccharides from inulin by immobilized endoinulinase from Pseudomonas sp. Journal of Fermentation and Bioengineering, 84:369-371.

Yun, J.W.; Kim, D.H.; Uhm, T.B. and Song, S.K. (1997b). Production of high content inulooligosaccharides from inulin by a purified endoinulinase. Biotechnology Letters, 19:935-938.

Zhao, M.; Mu, W.; Jiang, B.; Zhou, L.; Zhang, T.; Lu, Z.; Jin, Z. and Yang, R. (2011). Purification and characterization of inulin fructotransferase (DFA IIIforming) from Arthrobacter aurescens SK 8.001. Bioresource Technology, 102:1757-1764.

Citation: Shavnam Thakur, Adnan A. Khan and Wamik Azmi (2020). Potential of oligosaccharides from inulin in human nutrition and health. Ann. Phytomed., 9(1):141-146. http://dx.doi.org/10.21276/ap.2020.9.1.18 